Paweł Kubicki

Instytut Europeistyki | Uniwersytet Jagielloński

\title{
Wpływ studentyfikacji i turystyfikacji na społeczno-kulturową przestrzeń miasta
}

\# Kraków \# urbanistyka \# mieszkalnictwo \# turystyfikacja \# studentyfikacja \# gentryfikacja \# turystyka \# BPO \# kapitał społeczny

\# Kraków \# urban planning \# housing \# touristification \# studentification \# gentrification \# tourism \# BPO \# social capital

Artykuł analizuje zjawiska studentyfikacji i turystyfikacji oraz ich wpływ na społeczno-kulturową przestrzeń miasta. Wnioski dotyczą głównie Krakowa, ale mogą być użyteczne także dla większości dużych polskich miast. Kraków jest dobrym studium przypadku z uwagi na trzy cechy. Po pierwsze, jest największym po stolicy ośrodkiem akademickim; po drugie ,wyrósł na jedno z najważniejszych w świecie centrów sektora BPO (Business Process Outsourcing), co przekłada się na duży popyt na mieszkania na wynajem; po trzecie, przyciąga rocznie miliony turystów. Artykuł wykazuje, że im bardziej postępuje studentyfikacja i turystyfikacja, tym słabsza staje się tożsamość miasta, a kapitał społeczny ulega erozji. Radykalnie obniża się jakość życia, więc coraz częściej mieszkańcy decydują się na wyprowadzkę z miast, przyczyniając się do depopulacji i obumierania centrów.

The article analyzes the phenomena of studentification and touristification and their impact on the socio-cultural space of the city. The conclusions refer mainly to Kraków, but may also be useful for the majority of large Polish cities. Kraków is a good case study by reason of three characteristics. First of all, it is the second largest academic center after the capital city; secondly, it has grown into one of the most important BPO sector centers in the world (Business Process Outsourcing), which translates into high demand for rental housing; thirdly, it attracts millions of tourists every year. The article shows that along with the progress of studentification and touristification the identity of the city becomes weaker and its social capital erodes. Life quality is drastically reduced, so more often citizens decide to move out of cities, contributing to the depopulation and dying of centers.

Miasto. Pamięć i Przyszłość 2 (2017) ISSN 2543-621X

\section{OPEN ACCESS}

Citation: Kubicki P., Wpływ studentyfikacji i turystyfikacji na społeczno-kulturową przestrzeń miasta, "Miasto. Pamięć i Przyszłość: Wrocławski Rocznik Samorządowy" - No 2.

https://doi.org/10.26774/mpp.35

Editor: Katarzyna Uczkiewicz

Received: October, 2017

Accepted: December, 2017

Published: December, 2017

Copyright: @ Ośrodek „Pamięć i Przyszłość" This is an open access article distributed under the terms of the Creative Commons Attribution-ShareAlike Licence, which permits unrestricted use, distribution, and reproduction in any medium, provided the original author and source are credited, with indications if any changes are made. All derivative works must be licensed under the same licence.

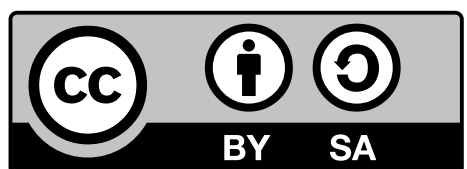


Dr hab. Paweł Kubicki - Socjolog, adiunkt w Instytucie Europeistyki UJ. Pracował w wielu międzynarodowych zespołach baadawczych, m.in.: "Ethnological Understanding of Cultural Diversity in Central European Urban Spaces", "La Place un patrimoine europée, The Square: a European Heritage" oraz "RECON Reconstituting Democracy in Europe". Autor m.in.: Miasto w sieci znaczeń. Kraków i jego tożsamości (2010) oraz raportu Nowi mieszczanie w nowej Polsce (2011). 


\section{Wstęp}

Artykuł ten jest poświęcony analizie dwóch zjawisk określanych jako studentyfikacja i turystyfikacja oraz wpływu, jaki wywierają na społeczno-kulturową przestrzeń miasta. Swoje wnioski wyprowadzać będę głównie w odniesieniu do przykładu Krakowa. Sądzę jednak, że pod wieloma względami przykład ten może być reprezentatywny także dla Wrocławia oraz większości dużych polskich miast. Kraków jest dobrym studium przypadku z uwagi na trzy charakterystyczne cechy. Po pierwsze, jest to po stolicy kraju największe centrum akademickie Polski, gdzie studenci stanowią znaczny i bardzo widoczny odsetek mieszkańców. W ostatniej dekadzie liczba studentów oscylowała wokół 200 tys. - przy niecałych 760 tys. stałych mieszkańców?. Po drugie, miasto to wyrosło na jedno z najważniejszych w świecie centrów sektora BPO (Business Process Outsourcing)², co przekłada się na duży popyt na mieszkania na wynajem dla młodych pracowników korporacji. Według raportu przygotowanego przez Związek Liderów

Miasto. Pamięć i Przyszłość 2 (2017) ISSN 2543-621X 65
Sektora Usług Biznesowych (ABSL) Sektor nowoczesnych usług biznesowych w Polsce 2017³, w sektorze BPO w 2017 r. pracowało w Krakowie 55,8 tys. osób, a w najbliższych latach ta liczba może wzrosnąć. Po trzecie wreszcie, to jedno z najatrakcyjniejszych turystycznie miast w Europie, przyciągające rocznie miliony turystów. Według danych przytaczanych przez oficjalny portal Urzędu Miasta Krakowa, w 2016 r. stolicę Małopolski odwiedziło 12,15 mln turystów 4.

\section{Ciemniejsza strona miejskiego odrodzenia. Gentryfikacja}

Przed przystąpieniem do zasadniczej analizy konieczne jest dookreślenie dwóch kluczowych pojęć używanych w artykule: studentyfikacji

1. M. Murzyn-Kupisz, M. Szmytkowska, Studentification In The Post-Socialist Context: The Case Of Cracow And The Tri-City (Gdansk, Gdynia And Sopot), Geografie, Čislo 2 Ročnik 120 (2015), s. 188-204.

2. W 2017 r. Kraków zajął ósme miejsce w rankingu Tholons Services Globalization Index 2017 - 100 najlepszych destynacji dla outsourcingu na świecie. Był najwyżej skalsyfikowanym miastem w Europie. W pierwszej dziesiątce z miast europejskich znalazły się tylko Kraków (8) i Dublin (10). Źródło: http://krakow.pl/aktualnosci/211419,26,komunikat,krakow_poprawil_miejsce_w_rankingu_lokalizacji_dla_outsourcingu.html (dostęp: 3 X 2017 r.).

3. http://g3.gazetaprawna.pl/p/_wspolne/pliki/2981000/ 2981561-raport-absl-2017.pdf (dostęp: 3 X 2017 r.).

4. http://krakow.pl/aktualnosci/205715,29,komunikat,rekordowy_rok_dla_krakowskiej_turystyki.html (dostęp: 3 X 2017 r.). 
i turystyfikacji. Terminy te weszły do słownika akademickiego stosunkowo niedawno i są ściśle powiązane z dobrze już opisanym zjawiskiem, jakim jest gentryfikacja, która jako zjawisko społeczne została po raz pierwszy opisana przez Ruth Glass w początkach lat 6o. ubiegłego wieku na przykładzie Londynu5. Początkowo gentryfikacja traktowana była jako zjawisko marginalne, m.in. dlatego, że lata 70. i 80. XX w. charakteryzowały się głębokim kryzysem miast Zachodu. W podupadających miastach trudno było dostrzec symptomy gentryfikacji. Sytuacja zaczęła się zmieniać z końcem ubiegłego wieku, kiedy to miasta Zachodu zaczęły się podnosić z kryzysu i dość powszechnie zaczęto obwieszczać nowy etap odrodzenia miejskiego ${ }^{6}$. Jednak wraz z postępującymi procesami odrodzenia rozwijała się także gentryfikacja, co powodowało, że ze zjawiska marginalnego stawała się ona coraz poważniejszym i coraz częściej dyskutowanym problemem, z jakim zmagają się współczesne miasta. Popularność danego zjawiska najczęściej nie przekłada się na jego operacjonalizację, co podkreślał Jacek Gądecki, pisząc, że gentryfikacja to pojęcie "na tyle szerokie, że - zdaniem licznych krytyków traci swoją moc wyjaśniającą i przydatność jako kategoria opisu procesów miejskich. W zasadzie

5. R. Glass, Aspects of Change, London 1964.

6. Więcej na ten temat: A. Majer, Odrodzenie miast, Łódź-Warszawa 2014.

7. J. Gądecki, I Love NH. Gentryfikacja starej części Nowej Huty?, Warszawa 2012, s. 30.

8. R. Florida, Narodziny klasy kreatywnej: oraz jej wpływ na przeobrażenia w charakterze pracy, wypoczynku, społeczeństwa i życia codziennego, tłum. T. Krzyżanowski, M. Penkala, Warszawa 2010.

9. Przykładowo badania nad gentryfikacją Greenpointu w Nowym Jorku: A. Sosnowska, Awans symboliczny mimochodem. Liderzy polskiego Greenpointu wobec gentryfikacji dzielnicy, "Politeja. Pismo Wydziału Studiów Międzynarodowych i Politycznych UJ", 27/2014. już w połowie lat 8o. XX w. uznano gentryfikację za koncepcję bardzo chaotyczną, a jednocześnie silnie nacechowaną ideologicznie"7. Z uwagi na ograniczone ramy artykułu pomijam w tym miejscu szczegółową analizę literatury przedmiotu poświęconej problematyce gentryfikacji. Dalej pod pojęciem gentryfikacji rozumieć będę procesy, w wyniku których „szlachetni” mieszkańcy wypierają z atrakcyjnych przestrzeni miasta "nieszlachetnych". Do kategorii "szlachetnych" zalicza się przede wszystkim tych, którzy są użyteczni dla tzw. przemysłów kreatywnych, usług i kulturowej konsumpcji, co stanowi koło zamachowe gospodarki odradzających się miast. Są to więc głównie przedstawiciele tzw. klasy kreatywnej ${ }^{8}$ o ponadprzeciętnych zasobach kapitałów kulturowych, społecznych i ekonomicznych, co czyni z nich idealnych konsumentów nowej gospodarki oferowanej przez odradzające się miasta. Co istotne dla dalszych rozważań, jako „szlachetnych” postrzega się także turystów i studentów - grupy w istotny sposób przyczyniające się do stymulowania takiej gospodarki.

Najczęściej zjawisko gentryfikacji opisywane jest w negatywnym kontekście, jako jedna z istotnych barier dla zrównoważonego rozwoju miast, osłabiająca ich tożsamość i więzi społeczne. Niemniej jednak pomimo wielu dysfunkcji, jakie zjawisko to wywołuje w społeczno-kulturowej tkance miasta, generuje ono pewne pozytywne skutkiª, czego nie da się już powiedzieć o studentyfikacji i turystyfikacji. Można przytoczyć wiele krytycznych argumentów

Miasto. Pamięć i Przyszłość 2 (2017) ISSN 2543-621X 
dotyczących wypychania uboższych mieszkańców z przestrzeni miejskich, w których dotychczas żyli. W klasycznym modelu gentryfikacji ich miejsce zajmują bogatsi, jednak to wciąż są "mieszkańcy” - tworzący więzi społeczne, identyfikujący się z daną przestrzenią i biorący za nią odpowiedzialność. Turystyfikacja10 i studentyfikacja11 przyczynia się tylko do tworzenia socjologicznej próżni: wypycha dotychczasowych mieszkańców (bez różnicy: biednych czy bogatych), a na ich miejsce wprowadza ludzi przepływów, nietworzących żadnych więzi społecznych, nieidentyfikujących się z przestrzenią, w której przebywają, i w żaden sposób niebiorących za nią odpowiedzialności. W dalszej części postaram się przedstawić najważniejsze przyczyny i skutki turystyfikacji i studentyfikacji.

\section{Turystyfikacja i studentyfikacja i ich skutki dla społeczności lokalnych}

Szereg czynników sprawił, że w ostatnich dekadach zaszły istotne zmiany w obrębie szeroko rozumianej turystyki. W efekcie na atrakcyjności turystycznej zaczęty zyskiwać same miasta. Według danych Eurostatu, w latach 2012-2014 liczba łóżek hotelowych w krajach UE wzrosła o 3,9 proc. Co jednak istotne, największy wzrost zanotowano w centrach dużych miastach - o ponad 10 proc., podczas gdy w mniejszych miastach i na przedmieściach było to 3,2 proc., natomiast na terenach wiejskich jedynie 1,3 proc.12. Trzeba jednak pamiętać, że oficjalne dane Eurostatu nie uwzględniają dynamicznie rozwijającej się sfery prywatnych

Miasto. Pamięć i Przyszłość 2 (2017) ISSN 2543-621X 67 mieszkań oferowanych jako baza turystyczna. Rozwój takich portali internetowych jak Couchsurfing czy Airbnb przyniósł prawdziwy boom na specyficzny rodzaj turystyki miejskiej, co generuje liczne negatywne skutki dla społeczno-kulturowej tkanki miast. Badacze tego zjawiska zwracają uwagę, że można wyróżnić kilka koncepcji tego, w jaki sposób turystyfikacja oddziałuje na miasto. (1) Koncepcja "przeciwstruktur”, która sugeruje pojawianie się w mieście obszarów, miejsc, obiektów prowokujących inne niż w codzienności style życia, aktywności, schematy interakcyjne. (2) Koncepcja "turystycznych baniek", która zwraca uwagę, że w miastach dochodzi do tworzenia enklaw turystycznych. Takimi bańkami mogą stawać się pojedyncze miejsca w mieście lub połączone korytarzami transmisyjnymi sieci miejsc. (3) "Tematyczność miejsc" to zjawisko obwołujące się do wykorzystywania nadrzędnego motywu w celu stworzenia holistycznej oraz zintegrowanej organizacji przestrzeni w mieście, w której znajdą się miejsca mające służyć społecznej konsumpcji. (4) „Podglądanie prawdziwego życia" (rubbernecking) - współcześnie dotyczy to zwłaszcza obszarów

10. Pod pojęciem turystyfikacji rozumiem procesy wywołane nadmiernym ruchem turystycznym, które przyczyniają się do niszczenia społeczno-kulturowej tkanki miasta: rozbijają sieci społeczne i sąsiedztwa, powodują erozję tożsamości lokalnych, wypieranych przez działania marketingowe adresowane do turystów.

11. Mowa tu o polskiej wersji studentyfikacji, kiedy to studenci (a także absolwenci) wynajmują krótkookresowo (przez rok) mieszkania na wolnym rynku, co powoduje, że w miastach nie tworzą się tzw. dzielnice studenckie z charakterystycznymi dla nich usługami i specyfiką.

12. K. Nabielek, D. Hamers, D. Evers, Cities in Europe - Facts and figures on cities and urban area, 2016, https://ec.europa.eu/futurium/en/system/files/ged/pbl_2016_cities_in_europe_23231.pdf, s. 139 . 
podupadłych, zamieszkiwanych przez ubogą ludność, a także społeczności przestępcze. Daje ono szanse pochwalenia się, że widziało się więcej i dotknęło "naprawdę prawdziwego życia”. (5) Koncepcja „nie-miejsca” Marca Augé, która odnosi się do zagospodarowanych przestrzeni naśladujących rzeczywiste miejsca. To obszary seryjnie wytwarzane, wzmacniające anonimowość oraz uniformizację zachowań społeczno-przestrzennych. (6) Spojrzenie na miasto poprzez narrację obszarów sceny i kulis³. Im bardziej więc postępuje turystyfikacja, tym silniejszej erozji ulega tożsamość miasta, a mieszkańcy tracą poczucie podmiotowości i sprawczości w swoich małych ojczyznach. Jeśli odnieść się do klasycznej Goffmanowskiej metafory o teatrze życia codziennego, mieszkańcy miasta z aktorów pierwszoplanowych stają się „halabardnikami”. Główne miejsce na miejskiej scenie zaczynają zajmować turyści i to pod ich potrzeby, gusta, zainteresowania dostosowuje się przestrzeń miejską, sprawiając tym samym, że stali mieszkańcy czują się coraz bardziej obco w swoich miastach. Na narastający problem turystyfikacji zwracał uwage prestiżowy brytyjski tygodnik „The Guardian”,

13. J. Kotus, M. Rzeszewski, A. Bajerski, Przyjezdni w strukturach miasta - miasto wobec przyjezdnych: studenci i turyści w mieście w kontekście koncepcji „city users”, Poznań 2015, s. 79-85.

14. https://www.theguardian.com/travel/2017/aug/10/anti-tourism-marches-spread-across-europe-venice-barcelona (dostęp: $3 \times 2017$ r.).

15. Przykładowo w miastach holenderskich stworzono alternatywną platformę „Fairbnb”. Serwis oferuje krótkie pobyty w myśl zasad zrównoważonego rozwoju: społeczność lokalna ma współuczestniczyć w procesie wynajmu oraz w zyskach, jakie on przynosi, http://www.miasto2077.pl/holendrzy-stworzyli-fairbnb-lepsza-wersje-popularnego-serwisu-airbnb/ (dostęp: 6 X 2017 r.).

16. A. Bajerski, Student jako użytkownik miasta: brytyjskie doświadczenia studentyfikacji, „Rozwój Regionalny i Polityka Regionalna” 31 (2015), s. 47-56. gdy publikował w sierpniu 2017 r. cykl artykułów o protestach w miastach europejskich przeciwko masowej turystyce ${ }^{14}$. Obecnie coraz więcej miast, przez które przelewa się krytyczna masa turystyczna, stara się ograniczyć skalę tego zjawiska, czego przykładem są m.in. coraz częstsze ograniczenia dla działalności takich serwisów jak Airbnb15.

W przypadku studentyfikacji, mimo że jest to zjawisko pod wieloma względami różniące się od turystyfikacji, konsekwencje dla społeczno-kulturowej tkanki miast są podobne. Studentyfikacja została najwcześniej i najpełniej zbadana w Wielkiej Brytanii, gdzie już na przełomie milenium zaczęto zwracać uwagę na społeczne, przestrzenne i ekonomiczne skutki gwałtownego wzrostu liczby studentów w przestrzeni miejskiej ${ }^{16}$. O ile studentyfikacja przejawia się w wielu wymiarach, o tyle jedną z jej najbardziej charakterystycznych cech jest to, że przyczynia się do spadku liczby stałych mieszkańców w okolicy, w której się rozwija. Im większa liczba mieszkań na krótkookresowy wynajem, tym bardziej spada jakość życia w danej okolicy, co staje się istotnym czynnikiem wypychającym mieszkańców.

Jeśli weźmie się pod uwagę wymienione czynniki, nie dziwi zmiana postaw wobec procesów, które były wskazywane jako stymulanty rozwoju miast. Jeszcze do niedawna rosnąca liczba studentów i turystów była prezentowana jako wyznacznik sukcesu i dynamiki miast. Od pewnego czasu coraz częściej pojawiają się poważne znaki zapytania: na ile wskaźniki te

Miasto. Pamięć i Przyszłość 2 (2017) ISSN 2543-621X 
przyczyniają się do faktycznego rozwoju miast, a na ile do obniżania jakości życia, do erozji więzi społecznych i osłabiania lokalnej tożsamości. Prawdą jest, że zarówno turyści, jak i studenci napędzają lokalny rynek i przynoszą miastom dochody. W praktyce jednak okazuje się, że nie są one wcale takie duże, gdyż specyfika branży turystycznej powoduje, że jej trudna do oszacowania część działa w szarej strefie, a miejsca pracy, które generuje, są najczęściej kiepsko płatne i mają niewiele wspólnego z innowacyjnością i kreatywnością. Ponadto coraz częściej beneficjentami boomu turystycznego są podmioty niezwiązane z danym miastem, ale jedynie inwestujące w infrastrukturę turystyczną (hotele, hostele, kluby i restauracje, mieszkania na wynajem itp.), zatem zyski i podatki transferowane są poza dane miasto.

Polskie miasta także są podatne na oddziaływanie powyższych procesów, choć uwarunkowane jest to lokalną specyfiką. W przypadku polskich miast o gentryfikacji pisze się sporo, jednak głównie w kontekście publicystycznym. Socjologiczne badania nie rozpoznają jeszcze tego zjawiska, a jeśli już, to jako gentryfikację marginalną ${ }^{17}$. Taka sytuacja specjalnie nie dziwi. Gentryfikacja, najprościej rzecz ujmując, jest odwrotnością procesu suburbanizacji. Na Zachodzie masowe osiedlanie się klasy średniej na rozrastających się przedmieściach było charakterystycznym procesem drugiej połowy XX w. Opuszczone centra miast podupadły. Jednak z końcem ubiegłego wieku rozpoczął się proces miejskiego odrodzenia - powrotu do miast

\section{Miasto. Pamięć i Przyszłość 2 (2017) ISSN 2543-621X}

- przede wszystkim wspominanej klasy średniej, będącej głównym aktorem stymulującym gentryfikację. Natomiast w przypadku polskich miast rodzima klasa średnia wciąż napędza proces suburbanizacji, a nie gentryfikacji. Co więcej, suburbanizacja finansowana jest często właśnie dzięki turystyfikacji i studentyfikacji. Domy pod miastem, budowane najczęściej na kredyt, finansowane są z wynajmu mieszkań dla studentów i turystów, a spadająca jakość życia w budynkach dotkniętych tymi procesami stymuluje wyprowadzkę kolejnych stałych mieszkańców poza miasto.

W Polsce studentyfikacja i turystyfikacja to problemy stosunkowo słabo rozpoznane empirycznie, którym poświęcono jak dotąd nieliczne badania naukowe ${ }^{18}$. Brakuje też wiarygodnych danych liczbowych pokazujących skalę zjawiska. Niemniej jednak jego badacze wychwytują pewne prawidłowości, do których można zaliczyć swoisty proces kolonizacji przestrzeni miejskiej. Piszą oni między innymi, że: „można wskazać na typowe dla obszarów skolonizowanych przez studentów przemiany funkcjonalno-przestrzenne oraz problemy społeczne [...]. Wraz z rosnącym udziałem studentów wśród mieszkańców dochodzi do stopniowej zmiany struktury świadczonych usług - rośnie udział m.in. sklepów z artykułami monopolowymi oraz obiektów gastronomicznych serwujących tanie jedzenie. Wzrostowi liczby studentów towarzyszy również zazwyczaj wzmożenie częstotliwości napięć pomiędzy mieszkańcami i studentami, których podłożem jest zazwyczaj nieprzestrzeganie

17. Por. J. Gądecki, op.cit.

18. Por.: M. Murzyn-Kupisz, M. Szmytkowska, op. cit.; J. Kotus, M. Rzeszewski, A. Bajerski, op. cit. 
przez studentów zarówno formalnych jak i nieformalnych zasad życia sąsiedzkiego"’19. Sytuacja ta spowodowana jest w dużej mierze tym, że w polskim kontekście studentyfikacja ma charakter raczej chaotyczny. Nie jest tu tak jak w klasycznym modelu studentyfikacji, gdzie studenci tworzą "wewnętrzne miasto”. Owszem, tzw. miasteczka studenckie charakterystyczne dla akademickich miast z epoki PRL wciąż funkcjonują, jednak mieszka w nich już niewielu studentów. Według badań Moniki Kupisz-Murzyn i Magdaleny Szmytkowskiej, prowadzonych wśród studentów Trójmiasta i Krakowa, jedynie 9-10 proc. studentów korzysta z bazy oferowanej przez uczelnie (akademiki)20. Większość współczesnych studentów wynajmuje mieszkania (pokoje) w miejscach, o których decydują dyktowane przez wolny rynek prawa podaży i popytu, które są bardzo zmienne. Najczęściej wynajem dotyczy jedynie roku akademickiego (9 miesięcy), jest więc krótkookresowy. To powoduje, że wynajmujący mieszkania nie są w stanie stworzyć więzi społecznych charakterystycznych dla sąsiedztwa: brakuje powtarzalnych interakcji, zaufania, identyfikacji z miejscem itp. Konsekwencją tego jest szybka degradacja "skolonializowanych” obszarów. Dzielnice, które jeszcze do niedawna były atrakcyjne dla najemców, szybko tę atrakcyjność tracą.

Dodatkowo w polskim (choć nie tylko) kontekście samo pojęcie studentyfikacji należy

19. J. Kotus, M. Rzeszewski, A. Bajerski, op. cit., s. 159.

20. Ibidem, s. 196.

21. Osobną kategorią są tzw. plastikowi studenci - osoby zapisujące się na studia, ale w praktyce niepodejmujące nauki. W tym przypadku chodzi przede wszystkim o „plastikową” legitymację studencką i ubezpieczenie, co czyni z nich atrakcyjnych pracowników na rynku pracy w sektorach stymulujących turystyfikację. rozszerzyć. Nie dotyczy ono wyłącznie formalnych studentów ${ }^{21}$, ale także absolwentów mieszkających w tzw. mieszkaniach studenckich jeszcze długo po zakończeniu studiów. Pomimo ogromnej podaży mieszkań oferowanych przez deweloperów i rynek wtórny w największych miastach ich ceny ciągle rosną i pozostają poza możliwościami wielu młodych ludzi wchodzących na rynek pracy. Dla wielu absolwentów wyższych uczelni podjęcie pracy zawodowej nie oznacza zakończenia nomadycznego trybu życia, gdyż zmuszeni są oni nadal do wspólnego (redukcja kosztów) wynajmowania mieszkań na podobnych zasadach jak w czasach studenckich i częstych przeprowadzek w obrębie miasta. Trudno podać dokładną liczbę takich miejskich nomadów. Biorąc za przykład tylko Kraków, za całkiem realny można przyjąć rząd wielkości 300-400 tys. osób. Na tę liczbę składa się wspomina już liczba ok. 200 tys. studentów i podobna liczba absolwentów (nie tylko krakowskich) uczelni, którzy mieszkają w wynajmowanych mieszkaniach i pracują głównie w dynamicznie rozwijającym się sektorze BPO oraz w branży usługowo-turystycznej. Co istotne, praca w tych branżach najczęściej nie przekłada się na długoterminową stabilizację zatrudnienia, a co za tym idzie - na zdolność kredytową konieczną dla zakupu własnego mieszkania. Ciekawych danych w tym kontekście dostarcza broszura Krakowski Rynek Nieruchomości 2015, wydana przez Wydział Rozwoju Miasta Urzędu Miasta Krakowa, w której można przeczytać m.in., że: „według danych Urzędu Statystycznego w Krakowie,

Miasto. Pamięć i Przyszłość 2 (2017) ISSN 2543-621X 
W ciągu 12 miesięcy 2015 roku w stolicy Małopolski oddano do użytku 6521 mieszkań [...]. Przez pięć ostatnich lat w Krakowie oddano w sumie ponad 32,5 tys. mieszkań. W tym samym czasie rozpoczęto budowę 47,3 tys. mieszkań"22. Z podanych danych wynika, że w ciągu dekady zasoby mieszkaniowe Krakowa wzrosną o ponad 80 tys. mieszkań. Przy założeniu, że przecięta rodzina liczy cztery osoby, zasoby te wystarczają dla 250 tys. osób. W ostatniej dekadzie ludność Krakowa (oficjalna) wzrosła jedynie o niecały tysiąc mieszkańców. Co więcej, opublikowane niedawno prognozy Instytutu Geografii i Przestrzennego Zagospodarowania Polskiej Akademii Nauk PAN wskazują, że Krakowowi grozi depopulacja i do 2050 r. miasto straci 11,3 proc. mieszkańców²3. Można zatem z dużą dozą prawdopodobieństwa założyć, że znakomita większość wprowadzonych na rynek mieszkań przeznaczana jest na wynajem, czemu sprzyjają opisywane powyżej procesy studentyfikacji i turystyfikacji. Taka sytuacja generować będzie bardzo poważne problemy dla miasta, co można zilustrować przykładem funkcjonowania wspólnot mieszkaniowych.

Wspólnota mieszkaniowa jest jednym z kluczowych elementów wpływających na jakość zamieszkania, więzi sąsiedzkie, poczucie bezpieczeństwa oraz kształtowanie się lokalnego społeczeństwa obywatelskiego. Grażyna Woroniecka, badając rolę wspólnot mieszkaniowych w kontekście działań politycznych na poziomie samorządów, zwracała uwagę, że wskutek zmian ustawowych dotychczasowa

Miasto. Pamięć i Przyszłość 2 (2017) ISSN 2543-621X 71 administracja komunalna (aktor organizacyjny) została formalnie zrównana w prawach ze współwłaścicielami indywidualnymi. Ważnym miejscem kontaktu aktora organizacyjnego z indywidualnym stały się walne zebrania wspólnot mieszkaniowych, a formą kontaktu - negocjowanie, w miejsce uprzedniego zawiadamiania (podkreślenia autorki)24. Powstała więc przestrzeń dla deliberacji - kluczowa dla kształtowania się demokracji lokalnej i budowania kapitału społecznego. Opisywane procesy studentyfikacji i turystyfikacji przyczyniają się do dekonstrukcji tej przestrzeni. Brakuje aktualnych badań, które pokazywałyby skalę problemu. Można w tym miejscu jedynie pokusić się o postawienie pewnych hipotez. Jeśli - na co wskazywałyby przytaczane powyżej argumenty - większość wprowadzanych na rynek nowych budynków mieszkalnych zasiedlają krótkookresowi najemcy, to wspólnoty mieszkaniowe będą działać ułomnie. Najemcy, którzy nie mają formalnego prawa głosu w sprawach wspólnoty, a najczęściej też wymieniają się co rok, nie są zainteresowani aktywnością na rzecz swojej wspólnoty lokalnej, nie tworzą więzi sąsiedzkich itp. Jedną z konsekwencji tego będzie szybka dekapitalizacja zasobów mieszkaniowych. Właściciele mieszkań kupowanych na wynajem są rozproszeni po całej Europie 25 , nie mogą zatem na bieżąco decydować o konserwacji, koniecznych remontach itp. Ponadto osłabione poczucie bezpieczeństwa

22. Krakowski Rynek Nieruchomości 2015, Kraków 2016., s. 25 23. https://www.igipz.pan.pl/home_pl.html (dostęp: 7 X 2017 r.). 24. G. Woroniecka, Działanie polityczne. Próba socjologii interpretatywnej, Warszawa 2001, s. 121-122.

25. Często to polscy emigranci lokują w ten sposób kapitał zarobiony na emigracji. 
wynikające z atomizacji więzi społecznych sprzyja rozwojowi zachowań dewiacyjnych: częstszym kradzieżom, wybrykom chuligańskim itp. Na wszystko to nakłada się problem reprezentacji politycznej, gdyż zatomizowana społeczność bez wspólnych celów nie jest w stanie wyłonić swojej reprezentacji do rad osiedlowych lub dzielnicowych.

\section{Podsumowanie}

Truizmem jest dziś pisanie, że o rozwoju miasta decyduje przede wszystkim siła jego tożsamości i kapitał społeczny. Im bardziej jednak postępują opisane powyżej zjawiska, tym słabsza staje się tożsamość miasta, a kapitał społeczny ulega erozji. W konsekwencji radykalnie obniża się jakość życia, co sprawia, że coraz częściej stali mieszkańcy decydują się na wyprowadzkę z miast. Depopulacja jest już poważnym problemem polskich miast, a prognozy wskazują, że tylko będzie się pogłębiać. Konieczne jest poszukiwanie rozwiązań mogących ograniczać dysfunkcyjne procesy wywołane przez studentyfikację i turystyfikację. 


\section{Bibliografia}

- A. Bajerski, Student jako użytkownik miasta: brytyjskie doświadczenia studentyfikacji, „Rozwój Regionalny i Polityka Regionalna" 31, 2015, s. 47-56.

- J. Gądecki, I Love NH. Gentryfikacja starej części Nowej Huty?, Warszawa 2012.

- R. Glass, Aspects of Change, London 1964.

- R. Florida, Narodziny klasy kreatywnej: oraz jej wpływ na przeobrażenia w charakterze pracy, wypoczynku, społeczeństwa i życia codziennego, tłum. T. Krzyżanowski, M. Penkala, Warszawa 2010.

- Krakowski Rynek Nieruchomości 2015, Kraków 2016.

- J. Kotus, M. Rzeszewski, A. Bajerski, Przyjezdni w strukturach miasta - miasto wobec przyjezdnych: studenci i turyści w mieście w kontekście koncepcji „city users", Poznań 2015.

- A. Majer, Odrodzenie miast, Łódź-Warszawa 2014.

- M. Murzyn-Kupisz, M. Szmytkowska, Studentification In The Post-Socialist Context: The Case Of Cracow And The Tri-City (Gdansk, Gdynia And Sopot), Geografie, Čislo 2 Ročnik 120 (2015).

- K. Nabielek, D. Hamers, D. Evers, Cities in Europe - Facts and figures on cities and urban area, 2016, https://ec.europa.eu/futurium/en/system/files/ ged/pbl_2016_cities_in_europe_23231.pdf.

- A. Sosnowska, Awans symboliczny mimochodem. Liderzy polskiego Greenpointu wobec gentryfikacji dzielnicy, "Politeja. Pismo Wydziału Studiów Międzynarodowych i Politycznych UJ", 27/2014.

- G. Woroniecka, Działanie polityczne. Próba socjologii interpretatywnej, Warszawa 2001.

\section{Witryny internetowe}

- http://krakow.pl/aktualnosci/211419,26,komunikat,krakow_poprawil_miejsce_w_rankingu_lokalizacji_dla_outsourcingu.html

- http://g3.gazetaprawna.pl/p/_wspolne/pliki/2981000/2981561-raport-absl-2017.pdf

- http://krakow.pl/aktualnosci/205715,29,komunikat,rekordowy_rok_dla_krakowskiej_turystyki.html https://www.igipz.pan.pl/home_pl.html

- https://www.theguardian.com/travel/2017/aug/10/ anti-tourism-marches-spread-across-europe-venice-barcelona http://www.miasto2077.pl/holendrzy-stworzyli-fairbnb-lepsza-wersje-popularnego-serwisu-airbnb/ 